\title{
Bacterioplankton growth responses to temperature and chlorophyll variations in estuaries measured by thymidine:leucine incorporation ratio
}

\author{
Fuh-Kwo Shiah ${ }^{1, *}$, Hugh W. Ducklow ${ }^{2}$ \\ ${ }^{1}$ Box 23-13, Institute of Oceanography, National Taiwan University, Taipei, Taiwan, ROC \\ ${ }^{2}$ Box 1346, Virginia Institute of Marine Science, The College of William and Mary, Gloucester Point, Virginia 23062-1346, USA
}

\begin{abstract}
To identify the biochemical response of heterotrophic bacterioplankton to changing environmental conditions, seasonal and diel cycles of bacterial protein and DNA synthesis rates were estimated in temperate estuarine habitats from ${ }^{3} \mathrm{H}$-leucine (Leu) and ${ }^{3} \mathrm{H}$-thymidine (TdR) incorporation rates. Several short-term temperature manipulation experiments $\left(5\right.$ to $\left.35^{\circ} \mathrm{C}\right)$ and 2 mesocosm experiments were performed to examine the effects of temperature and substrate supply on the ratio of Leu:TdR, respectively. The molar ratio of Leu to $T d R$ varied about 5 -fold (5.6 to 29.5) in the field and the values of the ratio were lower and more constant during high temperature $\left(>25^{\circ} \mathrm{C}\right)$ and high chlorophyll a $\left(>8.0 \mathrm{\mu g} \mathrm{l}^{-1}\right)$ periods. In the temperature manipulation experiments, the Leu:TdR ratio decreased as temperature increased. In the mesocosm experiments, the Leu:TdR ratio was negatively correlated with chlorophyll a concentrations and bacterial specific growth rates. We propose that changes toward less favorable environmental conditions (e.g. reductions in temperature or substrate supply in temperate estuaries) might reduce bacterial protein and DNA synthesis rates simultaneously. However, the former process may be favored to maximize survival and this might lead to a higher Leu:TdR ratio. Conversely, when environmental conditions turn favorable, both processes could be enhanced and bacteria might optimize DNA duplication over protein metabolism to maximize reproduction, resulting in lower Leu:TdR ratios. Our results further indicate the complementariness of ${ }^{3} \mathrm{H}$-thymidine and ${ }^{3} \mathrm{H}$-leucine incorporation measurements for understanding processes controlling bacterial production since the ratio of these 2 tracer methods varied independently with temperature and substrate supply.
\end{abstract}

KEY WORDS: Bacterioplankton - Diel and seasonal cycles - Estuary - DNA · Protein - Temperature . Unbalanced growth

\section{INTRODUCTION}

Although the study of heterotrophic bacterioplankton in aquatic ecosystems has exploded since the introduction of the 'microbial loop' concept (Pomeroy 1974, Azam 1986), there have been relatively few studies on biochemical adaptations of bacterioplankton to changing environmental conditions.

DNA and protein are the 2 major components of bacterial biomass and may constitute more than $70 \%$ of bacterial dry weight (Simon \& Azam 1989). The synthesis rates of DNA and protein represent 2 of the most

·E-mail: fkshiah@iodec1.oc.ntu.edu.tw basic processes within a bacterial cell, reproduction and biomass accumulation, respectively. Both pure culture and seawater culture studies have demonstrated that the synthesis rates of macromolecules (DNA, RNA and protein) can be coupled (i.e. balanced growth) or uncoupled (i.e. unbalanced growth) when bacterial specific growth rate changes (Brunschede et al. 1977, Harder et al. 1984, Chin-Leo \& Kirchman 1990, Servais 1992). Since bacterial growth rate can be affected by different environmental factors, such as substrate supply and temperature (Shiah \& Ducklow 1994a, 1995a), it has been proposed that the ratio of protein to DNA synthesis rates may provide useful insight into the growth responses of bacteria to changing substrate and physico-chemical conditions in 
dynamic natural environments (Simon \& Azam 1989, Riemann \& Bell 1990). Based on the response time (i.e. 4 to $16 \mathrm{~h}$ ) of bacteria in seawater culture experiments, Chin-Leo \& Kirchman (1990) further pointed out that measurements of growth status (i.e. balanced vs unbalanced growth) might be useful in identifying the factors that regulate bacterial growth in nature. Recently, Tibbles (1996) reported differential effects of temperature on thymidine and leucine incorporation, suggesting that these 2 cellular processes respond differently to changes in environmental factors. Tibbles' paper (1996) led us to reexamine our data sets to test new ideas about environmental regulation of bacterial growth states.

To address the question of how bacteria adjust their biochemical pathways to adapt to changing environmental conditions, we investigated seasonal and diel cycles of bacterial protein and DNA synthesis rates in a salt marsh tidal creek. In addition, we performed several short-term manipulation experiments to examine the biochemical responses of these 2 processes to temperature changes over a time scale of hours. To test the effect of substrate supply on the allocation of bacterial protein and DNA synthesis rates, two 2 wk indoor mesocosm experiments were performed.

\section{MATERIALS AND METHODS}

Study area and sampling. The Horn Point salt marsh tidal creek is located $4 \mathrm{~km}$ west of Cambridge, Maryland, USA. It flows into the Choptank River which is the largest sub-estuary on the eastern shore of the Chesapeake Bay. The creek is about $600 \mathrm{~m}$ long. The salinity ranges from 7 (low tide) to 15 psu (high tide) and the mean tidal amplitude is $0.5 \mathrm{~m}$. It is comparatively small in area but it has well developed vegetation zones (Stevenson et al. 1977).

Field study. Water samples were collected weekly in daytime at low tide in the tidal creek from April 1991 to September 1992. A total of 54 weekly samples were collected. Diel studies were performed in May, June and October 1991 and August 1992 in the tidal creek (Table 1). In the first 3 studies, water samples were taken at low mid and high tide over several tid.al cycles. In the August 1992 experiments, only low tide water samples were measured consecutively over several days.

Temperature manipulation experiments. A total of 6 temperature manipulation experiments were performed with samples taken at low tide in the tidal creek in 1991 and 1992 (Table 2). Water samples were pre-incubated at 7 different temperatures $(5,10,15,20,25$, $30^{\circ} \mathrm{C}$ and ambient; see Table 2) in opaque polycarbonate bottles for $1 \mathrm{~h}$ immediately after water collection. Temperature for each treatment was controlled within $\pm 1^{\circ} \mathrm{C}$.
Mesocosm experiments. Water from the Choptank River was filtered through a $164 \mu \mathrm{m}$ mesh into duplicate indoor, $400 \mathrm{l}$, acid washed fiberglass tanks. This 164 um filtration removed large metazoans and detritus. The tanks were conical with the bottom ending in a drain. Air stones at the bottom of the tanks provided circulation to keep particles in suspension. All tanks were incubated at $23^{\circ} \mathrm{C}$ and fluorescent lights suspended over the tanks provided light $12 \mathrm{~h} \mathrm{~d}^{-1}$. Since water from the Choptank River had been stored in the dark in a holding tank for several days, it was acclimated in the experimental mesocosm tanks with $12: 12 \mathrm{~h}$ light and dark for $2 \mathrm{~d}$ before starting the experiment.

We conducted separate mesocosm experiments in October and November 1991. In October, we simply observed the changes of measured variables (see below) over $14 \mathrm{~d}$ under low light conditions (1200 $\mu$ Einst $\mathrm{m}^{-2} \mathrm{~s}^{-1}$ ) without adding any nutrients. In November, we doubled the incubation light intensily and ammonium $\left(\mathrm{NH}_{4}{ }^{+}\right)$was added to duplicate tanks once a day to make a final concentration of $4.0 \mu \mathrm{M}$. Each day, the ambient $\mathrm{NH}_{4}{ }^{+}$concentration (Parsons et al. 1984) was measured immediately after sampling, then the amount of $\mathrm{NH}_{4}{ }^{+}$to be added to each tank was determined. No $\mathrm{NH}_{4}{ }^{+}$amendments were made whenever ambient concentration exceeded $4.0 \mu \mathrm{M}$. Tanks 1 and 2 received a total of 28.0 and $36.0 \mu \mathrm{M}$ of $\mathrm{NH}_{4}{ }^{+}$, respectively. Variables including bacterial abundance, ${ }^{3} \mathrm{H}$ thymidine and ${ }^{3} \mathrm{H}$-leucine incorporation rates (see below) and chlorophyll a (chl a) concentrations (Parsons et al. 1984) were measured daily.

Bacterial abundance. Bacterial abundance was determined by the acridine orange direct count method (Hobbie et al. 1977) as described previously (Shiah \& Ducklow 1994a).

DNA synthesis rates and specific growth rates. ${ }^{3} \mathrm{H}$ thymidine incorporation (Fuhrman \& Azam 1980, 1982) with chloroform-phenol extraction (Wicks \& Robarts 1987) was used to estimate the amount of labeled thymidine incorporated into DNA. Duplicate or triplicate 10 to $20 \mathrm{ml}$ aliquots of freshly collected water or pre-incubated samples (for temperature manipulation experiments) were incubated with ${ }^{3} \mathrm{H}$-[methyl]-thymidine (specific activity, 20 to $85 \mathrm{Ci} \mathrm{mmol}^{-1}$, final conc. $10 \mathrm{nM}$ ) in opaque polycarbonate bottles at different temperatures for 0.5 to $1.0 \mathrm{~h}$. Incorporation was stopped by adding formaldehyde (final conc. $1 \%$ ). Killed samples including time zero controls were mixed with $0.5 \mathrm{ml} 5 \mathrm{~N} \mathrm{NaOH}$ solution and stored in ice, then were filtered through $0.2 \mu \mathrm{m}$ cellulose nitrate filters within $24 \mathrm{~h}$. After the addition of $2.8 \mathrm{ml}$ ice cold $100 \%$ trichloroacetic acid, filters were rinsed 3 times each with chloroform-phenol $(1: 1, v: v)$ solution and ice cold $80 \%$ ethyl alcohol, respectively. Scintillation

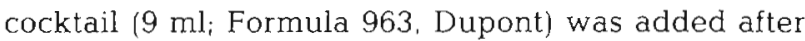


dried filters were dissolved completely in $1.0 \mathrm{ml}$ of ethyl acetate. Radioactivity in vials was counted by liquid scintillation (Packard, 2200CA). ${ }^{3} \mathrm{H}$-thymidine incorporation rates normalized by bacterial abundance were used as indices of bacterial specific growth rates.

Protein synthesis rates. Bacterial protein synthesis rates were determined by ${ }^{3} \mathrm{H}$-leucine incorporation (Kirchman et al. 1985, Chin-Leo \& Kirchman 1988). Water samples were incubated with $\mathrm{L}-\left[3,4,5-{ }^{3} \mathrm{H}-(\mathrm{N})\right]-$ leucine (final conc. $22 \mathrm{nM}$; $1 \mathrm{nM}$ labeled and $21 \mathrm{nM}$ unlabeled leucine). Killed samples were filtered through $0.2 \mu \mathrm{m}$ polycarbonate filters, then rinsed 4 times with ice cold $5 \%$ trichloroacetic acid and 4 times with $80 \%$ ethyl alcohol. Scintillation cocktail $(10 \mathrm{ml})$ was added after filters were dried in their vials at $35^{\circ} \mathrm{C}$ overnight

Data analysis. Statistical analysis including linear regression (Model II), multiple regression and the Kolmogorov-Smirnov test were performed using SYSTAT
(Wilkinson et al. 1992). To equalize the variance,-bacterial thymidine incorporation rates and leucine incorporation rates were log transformed. Normality of transformed data was tested by the KolmogorovSmirnov test.

\section{RESULTS}

\section{Field data}

Temperature showed a very strong seasonal signal (Fig. 1A), ranging from 0.5 to $34^{\circ} \mathrm{C}$ during study period. Chl a concentrations ranged from 1 to $34 \mu \mathrm{g} \mathrm{l}^{-1}$, basically following the same trend as temperature except for the phytoplankton bloom in April 1992 (Fig. 1B). Bacterial thymidine incorporation rates (i.e. TdR) and leucine incorporation rates (i.e. Leu) increased expo-

Table 1. List of temperature ( $T$ ), chl a concentrations ( $\mathrm{Chl} \mathrm{a)} \mathrm{and} \mathrm{the} \mathrm{range,} \mathrm{mean,} \mathrm{standard} \mathrm{deviation} \mathrm{(SD)} \mathrm{and} \mathrm{coefficient} \mathrm{of} \mathrm{vari-}$


at $\mathrm{p}<0.01$

\begin{tabular}{|c|c|c|c|c|c|c|}
\hline & $T\left({ }^{\circ} \mathrm{C}\right)$ & $\mathrm{Chl} a\left(\mu \mathrm{g} \mathrm{l^{-1 }}\right)$ & $\begin{array}{l}\text { Leu:TdR ratio } \\
\text { (range) }\end{array}$ & $\begin{array}{l}\text { Leu:TdR ratio } \\
(\text { mean } \pm S D)\end{array}$ & $\begin{array}{c}\text { Leu: TdR ratio } \\
\text { (CV) }\end{array}$ & $\begin{array}{l}\text { Sample size } \\
\text { (n) }\end{array}$ \\
\hline \multicolumn{7}{|l|}{ Weekly } \\
\hline All & $0.5-34$ & $1.3-34.9$ & $5.6-24.8$ & $10.0 \pm 3.7$ & $37 \%$ & 54 \\
\hline$T<25^{\circ} \mathrm{C}$ & - & $1.3-34.9$ & $5.6-24.8$ & $10.2 \pm 4.3$ & $42 \%$ & 36 \\
\hline$T>25^{\circ} \mathrm{C}$ & - & $6.6-28.8$ & $7.0-13.7$ & $9.6 \pm 2.2$ & $23 \%$ & 18 \\
\hline Chl $a<8.0$ & & - & $5.6-20.9$ & $10.6 \pm 4.3$ & $40 \%$ & 19 \\
\hline Chl $a>8.0$ & & - & $6.0-13.7$ & $9.5 \pm 2.2$ & $23 \%$ & 31 \\
\hline \multicolumn{7}{|l|}{ Diel } \\
\hline All & $18-34$ & $2.5-44.3$ & $6.0-29.5$ & $10.3 \pm 4.5$ & $43 \%$ & 47 \\
\hline May 91 & $18-28$ & $2.5-5.9$ & $6.6-29.5$ & $13.3 \pm 6.1$ & $46 \%$ & 17 \\
\hline Jun 91 & $27-31$ & $11.7-27.6$ & $6.2-8.3$ & $7.2 \pm 0.7$ & $9 \%$ & 11 \\
\hline Oct 91 & $19-24$ & $6.1-44.3$ & $6.0-10.5$ & $8.1 \pm 1.3$ & $16 \%$ & 9 \\
\hline Aug 92 & $23-34$ & $9.5-28.8$ & $8.3-13.3$ & $10.8 \pm 1.7$ & $15 \%$ & 10 \\
\hline$T<25^{\circ} \mathrm{C}$ & - & $2.5-44.3$ & $6.0-29.5$ & $11.5 \pm 5.1^{\circ}$ & $44 \%$ & 30 \\
\hline$T>25^{\circ} \mathrm{C}$ & - & $5.5-28.8$ & $6.2-13.3$ & $8.2 \pm 2.0^{\circ}$ & $25 \%$ & 17 \\
\hline Chl $a<8.0$ & & - & $6.6-29.5$ & $12.9 \pm 5.8^{\mathrm{a}}$ & $45 \%$ & 19 \\
\hline Chl $a>8.0$ & & - & $6.0-13.3$ & $8.6 \pm 2.0^{\mathrm{a}}$ & $24 \%$ & 28 \\
\hline
\end{tabular}

Table 2. In situ temperature $(T$ ), chl a concentrations ( $\mathrm{Chl}$ a), initial ratios of leucine to thymidine incorporation rate (Leu:TdR) and the slopes of $\log _{10} T d R, \log _{10}$ Leu and the Leu:TdR ratio on temperature of the temperature manipulation experiments

\begin{tabular}{|c|c|c|c|c|c|c|c|}
\hline Expt & Date & $\begin{array}{c}T \\
\left({ }^{\circ} \mathrm{C}\right)\end{array}$ & $\begin{array}{c}\text { Chl a } \\
\left(\mu \mathrm{g} \mathrm{l}^{-1}\right)\end{array}$ & $\begin{array}{c}\text { Leu:TdR } \\
(\text { mean } \pm \text { SD) }\end{array}$ & $\begin{array}{l}\text { Slope }^{a}( \pm \text { SD) of } \\
\log _{10} \mathrm{TdR} \text { on } T\end{array}$ & $\begin{array}{l}\text { Slope }( \pm \text { SD) of } \\
\log _{10} \text { Leu on } T\end{array}$ & $\begin{array}{l}\text { Slope }^{\mathrm{b}}( \pm \mathrm{SD}) \text { of } \\
\text { Leu:TdR ratio on } T\end{array}$ \\
\hline 1 & Jun 1991 & 35 & 15.7 & $8.0 \pm 1.0$ & $0.049 \pm 0.003$ & $0.055 \pm 0.004$ & $-0.13 \pm 0.05$ \\
\hline 2 & Oct 1991 & 12 & 4.9 & $9.5 \pm 0.1$ & $0.060 \pm 0.004$ & $0.059 \pm 0.005$ & $-0.08 \pm 0.01$ \\
\hline 3 & Jan 1992 & 3 & 2.4 & $17.6 \pm 1.7$ & $0.046 \pm 0.005$ & $0.040 \pm 0.005$ & $-0.49 \pm 0.04$ \\
\hline 4 & Feb 1992 & 5 & 4.8 & $17.4 \pm 0.5$ & $0.040 \pm 0.002$ & $0.041 \pm 0.003$ & $-0.55 \pm 0.09$ \\
\hline 5 & May 1992 & 12 & 14.4 & $8.0 \pm 0.1$ & $0.045 \pm 0.003$ & $0.055 \pm 0.003$ & $-0.34 \pm 0.05$ \\
\hline 6 & Jun 1992 & 32 & 18.5 & $6.7 \pm 0.4$ & $0.065 \pm 0.004$ & $0.046 \pm 0.006$ & $-0.07 \pm 0.01$ \\
\hline
\end{tabular}



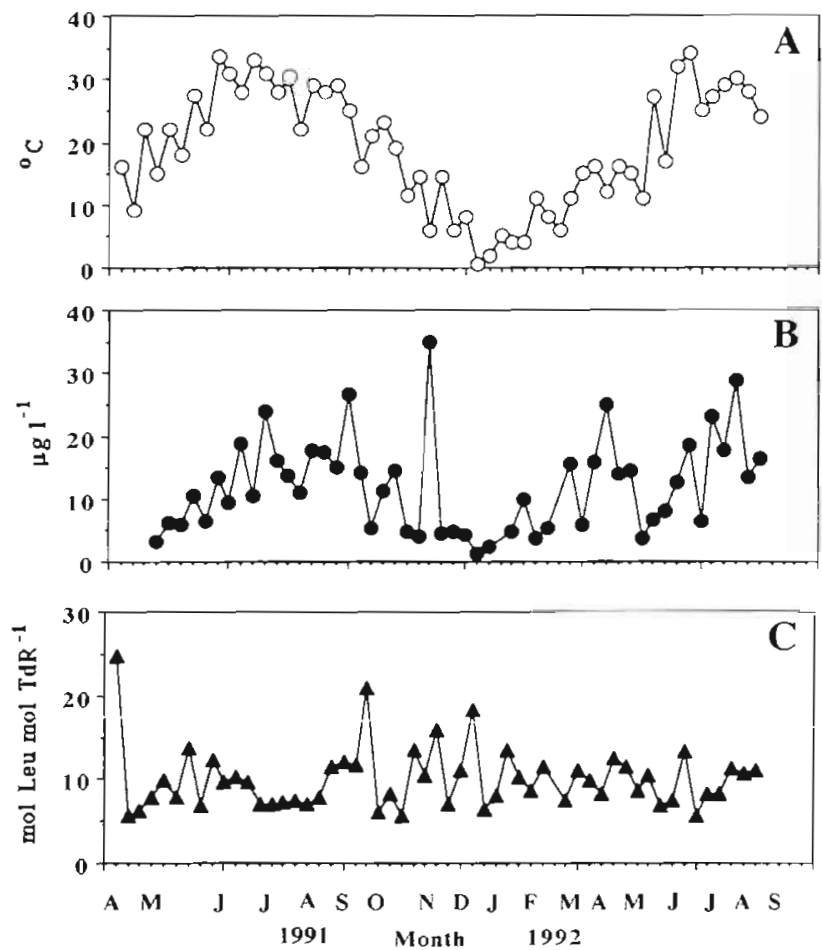

Fig. 1. Weekly change of the measured variables in the saltmarsh tidal creek, April 1991 to September 1992. (A) Temperature $_{i}$ (B) chlorophyll a concentrations; (C) ratios of leucine incorporation rate to thymidine incorporation rate nentially with temperature up to about $25^{\circ} \mathrm{C}$ (Fig. $2 \mathrm{~A}$, B). Multiple regression was performed to analyze the relative impact of temperature and $\mathrm{chl} a$ on $\mathrm{TdR}$ and Leu. Temperature alone explained 82 and $81 \%$ of the variability of TdR and Leu, respectively, and is clearly the major factor driving variations in TdR and Leu. After including chl $a$ in the model, the $\mathrm{R}^{2}$ values (coefficient of determination) for both parameters increased $<4 \%$. Thymidine incorporation rates per cell (i.e. $\mathrm{TdR}$ cell ${ }^{-1}$ ) also showed a positive relationship with temperature (Fig. $2 \mathrm{C} ; \mathrm{R}^{2}=0.80, \mathrm{p}<0.01, \mathrm{n}=54$ ). For the data $<25^{\circ} \mathrm{C}$, the slopes of $\log _{10} \mathrm{Leu}, \log _{10} \mathrm{TdR}$ and $\log _{10} \mathrm{TdR}_{\mathrm{cell}}{ }^{-1}$ on temperature were $0.099 \pm 0.008$, $0.103 \pm 0.009$ and $0.075 \pm 0.009$, respectively $\left(R^{2}>0.81\right.$, $\mathrm{p}<0.001, \mathrm{n}=34$ ). Leu and TdR were positively correlated (Fig. 2D). In the 4 diel studies, when pooled together, $\log _{10} \mathrm{TdR}, \log _{10}$ Leu and $\log _{10} \mathrm{TdR} \mathrm{cell}^{-1}$ were also positively correlated with temperature, respectively (Fig. 2A-C). Leu in the diel studies was positively correlated with TdR (Fig. 2D). The slopes of Leu vs TdR of the weekly and the pooled diel data were $8.62 \pm 0.55$ and $8.54 \pm 0.72$, respectively.

The molar ratio of these 2 rate parameters (i.e. Leu: $(d R)$ varied about 5 -fold in both the weekly (Fig. $1 C_{i} 5.6$ to 24.8 ) and the diel (6.0 to 29.5) studies (Table 1). The mean values of the Leu:TdR ratio in both studies (10.0 \pm 3.7 and $10.3 \pm 4.5)$ were not significantly
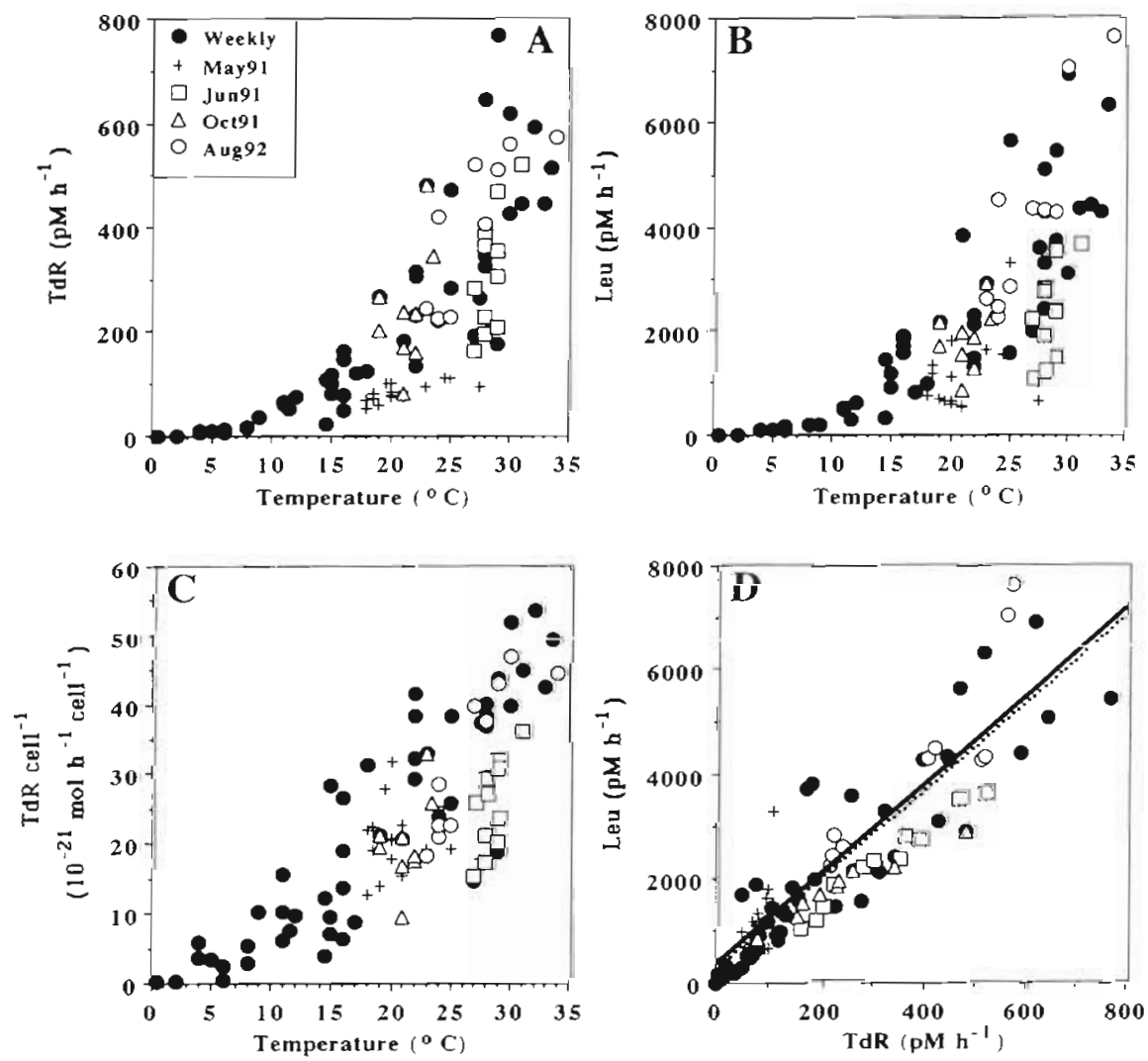

Fig. 2. Scatter plots of (A) temperature vs thymidine incorporation rates $(T d R)_{i}(B)$ temperature vs leucine incorporation rates (Leu): (C) temperature vs thymidine incorporation rate per cell; and (D) Leu vs TdR of the weekly and the 4 diel studies. Solid line in (D). the weekly data, Leu $=235+8.62$ $( \pm 0.55) \times T d R, R^{2}=0.82, n=54, p<$ 0.001 ; dashed line in (D), the pooled diel data, Leu $=201+8.54( \pm 0.72) \times$ $T d R, R^{2}=0.76, n=47, p<0.001$ 
different from each other ( $t$-test, $p>$ $0.05)$. Neither temperature nor chl a concentrations correlated with the Leu:TdR ratio in the weekly study. However, we found that the Leu:TdR ratio was less variable during high temperature (i.e. $>25^{\circ} \mathrm{C}$; Fig $3 \mathrm{~A}$ ) and high chl a (i.e. $>8.0 \mu \mathrm{g} \mathrm{l}^{-1}$; Fig. 3B) periods. The same phenomenon was also observed in the diel studies (Fig. 3C, D). For the weekly data set, the coefficients of variation (CV) of the $>25^{\circ} \mathrm{C}$ group (CV $\left.=23 \%\right)$ and the $>8 \mu \mathrm{g} \mathrm{l}^{-1}$ group $(\mathrm{CV}=23 \%)$ were about only half of their counterparts, respectively (Table 1). The diel data set also showed the same trend and, more importantly, the mean values of the $>25^{\circ} \mathrm{C}$ and the $>8 \mu \mathrm{g} \mathrm{l}^{-1}$ groups were significantly lower than their counterparts, respectively ( $t$-test, $\mathrm{p}<0.01$ ).

\section{Temperature manipulation experiments}

The in situ temperature, chl $a$ and the initial values of Leu:TdR ratio for water samples from different seasons, taken for temperature manipulation, ranged 3 to $35^{\circ} \mathrm{C}, 2.4$ to $18.5 \mu \mathrm{g} \mathrm{l}^{-1}$ and 6.7 to 17.6 , respectively (Table 2 ). After $\log _{10}$ transformation, the initial Leu:TdR ratios were negatively correlated with in situ temperature $(\mathrm{r}=-0.81, \mathrm{p}<0.01, \mathrm{n}=6)$ and $\mathrm{chl} a$ $(\mathrm{r}=-0.88, \mathrm{p}<0.01, \mathrm{n}=6)$, respectively. After incubation at different temperatures, $\log _{10}$ Leu, $\log _{10}$ TdR and $\log _{10} \mathrm{TdR}$ cell ${ }^{-1}$ increased linearly with incubation temperature in all 6 experiments (Table 2; and see Shiah \& Ducklow 1995b). The Leu:TdR ratios derived from the non-summer samples decreased with increasing temperature (Fig. 4A). The Leu:TdR ratio of the manipulated summer samples was positively correlated with temperature $<20^{\circ} \mathrm{C}$ and negatively correlated with temperature $>20^{\circ} \mathrm{C}$ (Fig. $4 \mathrm{~B}$ )

\section{Mesocosm experiments}

Fig. 5A-C shows the daily changes of measured variables during the 2 mesocosm experiments. In October, chl a was $1.64 \mu^{-1} \mathrm{~g}^{-1}$ at the beginning of the experiment, reached a maximum of $4.8 \mu \mathrm{g} \mathrm{l}^{-1}$ on Day 5 , then declined to $<2.0 \mathrm{Mg}^{-1}$ and remained low after Day 11 (Fig. 5A). Under higher light intensity and $\mathrm{NH}_{4}{ }^{+}$addition, chl a in November basically followed the same trend as in October, but with much higher concentra- tions (29.3 $\mu \mathrm{g} \mathrm{l}^{-1}$ ) from Days 2 to 6. After Day 6, chl a started to decrease and reached its minimum values $\left(<0.3 \mu \mathrm{g} \mathrm{l}^{-1}\right)$ after Day 9. TdR cell ${ }^{-1}$ ranged 4.6 to 10.4 and 1.2 to $18.2 \times 10^{-21} \mathrm{~mol} \mathrm{~h}^{-1} \mathrm{cell}^{-1}$ in October and November, respectively (Fig. $5 \mathrm{~B}$ ). In both experiments, values of $\mathrm{TdR}$ cell ${ }^{-1}$ were low at the beginning and then reached maxima on Day 7 . After Day $7, \mathrm{TdR}_{\mathrm{C}} \mathrm{Cll}^{-1}$ decreased during the period of chl a decline (Fig. 5A). There was a 1 or $2 \mathrm{~d}$ lag between the maxima of chl a and TdR cell ${ }^{-1}$. TdR cell ${ }^{-1}$ was positively correlated with chl $a$ after the 1 or 2 d lag period was adjusted. The correlation coefficients for chl a vs TdR cell-1 in October and November were +0.93 ( $1 \mathrm{~d}$ lag; $\mathrm{n}=13, \mathrm{p}<0.01$ ) and +0.84 ( 2 d lagi $\mathrm{n}=11, \mathrm{p}<0.01$ ), respectively. The ratio of Leu:TdR in October ranged from 16.2 to 40.8 and varied between 24.7 and 49.9 in November. The trends of Leu:TdR ratio in both experiments were opposite to those of chl $a$. The correlation coefficients for chl a vs Leu:TdR ratio in October and November were -0.72 $(\mathrm{p}<0.01, \mathrm{n}=14)$ and $-0.84(\mathrm{p}<0.01, \mathrm{n}=13)$, respectively. Note that the variations of the Leu:TdR ratio were similar in October and November (2- to 2.5-fold), even though the magnitude of chl a 'blooming' was greater in November $\left(0.3\right.$ to $\left.29.3 \mathrm{\mu g}^{-1}\right)$ than in October (1.6 to $4.8 \mu \mathrm{g}^{-1}$ ). 

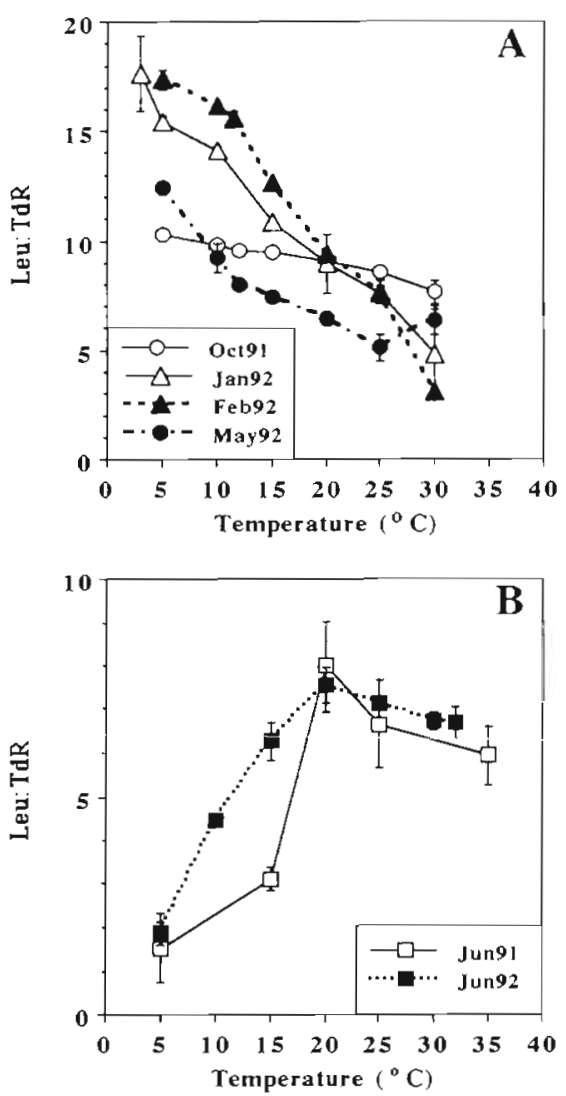

Fig. 4. Leu:TdR ratio vs temperature for the manipulation experiments performed during (A) non-summer and (B) summer periods. Vertical bars: standard deviation of triplicate measurements

\section{DISCUSSION}

The Leu:TdR ratios derived from our field surveys (5.6 to 29.5) and the mesocosm experiments (16.2 to 49.9) are in good agreement with previous data. In several enclosure experiments in lakes, Riemann \& Bell (1990) showed that Leu:TdR ratios varied more than 10 -fold over the diel period, ranging from ca 2.0 to 27.0 with averages of 8.8 to 9.0 . Chin-Leo \& Kirchman (1990) reported that the Leu:TdR ratio for estuarine bacteria in seawater culture experiments varied from $<5.0$ to $>70.0$. In summarizing bacterial thymidine and leucine incorporation rates from different aquatic ecosystems, Servais (1992) found that the average molar ratio of Leu to $\mathrm{TdR}$ incorporation was in the range 7.0 to 9.5 . For brackish water bacteria, the Leu:TdR ratio ranged from 5.0 to 30.0 (Heinanen \& Kuparinen 1992). These studies all showed that the Leu:TdR ratio varied either in the field or in laboratory experiments, although possible controlling mechanisms were not specifically analyzed.


Fig. 5. Daily change of the measured variables in the mesocosm experiment performed in October 1991 (O, left axis) and November 1991 ( $\bullet$, right axis). (A) Chl a concentrations; (B) thymidine incorporation rate per cell; and (C) ratio of Leu:TdR. Vertical bars: standard deviation of duplicate tanks

Growth and reproduction are the 2 basic goals for all living organisms. For unicellular organisms such as bacteria, these 2 functions can be represented by protein and DNA synthesis rates, respectively. In nature, resource supply and temperature are the 2 principal factors that may influence bacterial growth and reproduction. We speculate that bacteria may change relative rates of these 2 processes when living conditions change. More exactly, we hypothesize that favorable environmental conditions might enhance bacterial protein and DNA synthesis rates simultaneously, but favor the latter process to maximize reproduction, resulting in lower ratios of protein:DNA synthesis rates. On the other hand, when environmental conditions turn adverse (i.e. less optimal temperature or reduced substrate supply), both processes slow and bacteria might concentrate more on biomass accumu- 
lation than on reproduction to maximize the chance of survival, leading to higher ratios of protein:DNA synthesis rates.

The ratio of Leu:TdR will vary during non-steady state conditions, when environmental factors force reorganization of cellular biomass (unbalanced growth; Chin-Leo \& Kirchman 1990). In addition, the Leu:TdR ratio can also vary as a function of growth rate during balanced growth under more constant environmental conditions. That is, bacterial populations growing at different rates will have different relative rates of DNA and protein synthesis because the cellular quotas of protein and DNA (and other constituents) vary as a function of growth rate (Kjeldegaard et al. 1958). Our observations bear on these 2 mechanisms of Leu:TdR variability.

In the following sections, we first discuss the temperature manipulation and mesocosm data, and then the results of the field studies. The temperature manipulation and mesocosm studies address shorter-term variations, likely to be associated with transitions between growth states and rates, that is, variations due to unbalanced growth. In contrast, the field studies address longer time scales and are more likely to represent variations associated with different steady state, balanced growth conditions. We also address 2 factors which cause Leu:TdR ratio variations (i.e. temperature and substrate supply) separately.

Leu:TdR ratios varied more during short-term observations in the manipulation experiments (3- to 5 -fold in a few hours) than in the field and mesocosm observations, suggesting that Leu:TdR ratio variability is greater during unbalanced than balanced growth. These experiments clearly demonstrate the influence of temperature changes on growth state and biochemical organization in temperate, mesophilic bacterioplankton. As shown in earlier studies and in our data presented here (e.g. Fig. 2), temperate estuarine bacteria possess temperature optima around 25 to $30^{\circ} \mathrm{C}$, irrespective of the season and ambient temperature. Thus, as temperature rises toward more optimal conditions, Leu:TdR declines as bacteria favor division over protein synthesis (Fig. 4A).

We do not know why the temperature responses of the Leu:TdR ratio of the summer samples (Fig. 4B) were opposite to the trend of the non-summer experiments (Fig. 4A). In these manipulation experiments, we forced bacteria to experience the entire annual temperature range (i.e. $<5$ to $35^{\circ} \mathrm{C}$ ) over a few hours. In the field, the actual change of in situ temperature at shorter time scales (i.e. hours to weeks) seldom exceeded $15^{\circ} \mathrm{C}$ (Table 1). Thus, to interpret these temperature manipulation data more properly, one should consider the possible range of in situ temperature that bacteria might experience at shorter time scales. For example, the summer and winter bacteria may never experience temperatures $<20$ and $>20^{\circ} \mathrm{C}$ in the field, respectively. Therefore only the temperature responses of the Leu:TdR ratio within 10 to $15^{\circ} \mathrm{C}$ of the in situ temperature should be considered normal. However, this argument still does not explain why bacteria in non-summer seasons are capable of metabolic adjustments to such a wide temperature range.

The longer-term field data showed that bacteria with different growth rates had different ratios. Bacteria at higher temperatures had higher TdR cell-1 (e.g. Fig. 2) and also both lower variability (Table 1; weekly and diel data) and lower mean values (Table 1; diel data) for the Leu:TdR ratio. The weekly observations are more likely to represent balanced growth, although we cannot verify this assumption.

Many studies have demonstrated that substrate supply can be important in regulating bacterial growth rates and production (Cole et al. 1988, Shiah \& Ducklow 1994 a, b). However, it is difficult to evaluate the effects of substrate supply on bacterial growth and thus the Leu:TdR ratio using field data. In coastal and estuarine ecosystems, substrate required for bacterial growth may come from alloch thonous (e.g. riverine inputs, sediment resuspension) and autochthonous (e.g. phytoplankton exudation, excretion from planktonic organisms, sloppy feeding) sources. The complexity of these inputs has made the accurate measurement of substrate supply rates in the field extremely difficult (Ducklow \& Carlson 1992). In addition, the effect of substrate limitation might be confounded by physical factors such as temperature (Shiah \& Ducklow 1995a). Finally, physiological changes of the Leu:TdR ratio may occur at very short time scales (i.e. minutes to hours) while most of the field surveys such as our weekly study are performed over intervals of several days, weeks or even months. These 3 problems can be minimized in mesocosm experiments. That is, allochthonous substrate input can be cut off, the physical environment can be maintained and the physiological responses of the Leu:TdR ratio can be observed at a daily scale over an extended period which is difficult to accomplish in the field (Roman et al. 1988, Shiah \& Ducklow 1995b).

Since phytoplankton are the ultimate source for bacterioplankton growth in the absence of external sources, chl a could be viewed as an index of substrate supply rate in a closed system such as the mesocosm tanks in our experiment. The results of our mesocosm experiments suggest that substrate supply could affect bacterial growth rates and thus the Leu:TdR ratio when temperature was maintained. As the system approached a more substrate limited condition when chl a started to decline (Fig. 5A $A_{i}$ Days 6 to 9 in October and Days 5 and 6 in November), TdR $\mathrm{cell}^{-1}$ decreased correspondingly (Fig. 5B), but the 
ratio of Leu:TdR began to increase (Fig. 5C). This suggests that as growth conditions turn unfavorable (i.e. reduction in substrate supply), bacteria tend to favor protein synthesis over cell division. Our results also show instance of low Leu:TdR ratio values under low temperature and/or low chl a (i.e. low substrate) conditions. Chl a undoubtedly is an imperfect index of substrate supply, especially in estuarine habitats. For example, zooplankton grazing can result in low chl $a$, but substrate supply rates for bacterial growth can be still high due to the sloppy feeding effects. The bacterial Leu:TdR ratio could also be low under low chl a condition if the supply rates of substrate from non-phytoplankton sources and allochthonous inputs were high. We note that the Leu:TdR ratios in the mesocosm experiments were much higher than in the field, and have no explanation for this effect at this time.

In general, temperature appears to play a more important role than substrate supply in regulating estuarine bacterial growth (Berman et al. 1994). We observed the same phenomenon and suggest that temperature played a more important role than substrate supply in limiting bacterial growth during non-summer seasons when temperature was less than ca 20 to $25^{\circ} \mathrm{C}$ (Shiah \& Ducklow 1994a, b, 1995a).

Bacterial growth rates and thus their regulation of macromolecule synthesis in the field must be affected by substrate supply rates and temperature simultaneously. This can be verified by comparing the variability of the Leu:TdR ratio derived from the mesocosm and temperature manipulation experiments with those of the field data. The Leu:TdR ratio varied about 5 -fold over diel scale (Table 1). Under stable physical conditions in the mesocosms, the Leu:TdR ratio varied 2.0 - to 2.5-fold when substrate supply rates changed (Fig. 5C). In the temperature manipulation experiments, the Leu:TdR ratio varied 1.2 - to 2.3 -fold within the possible range of temperature (i.e. 10 to $15^{\circ} \mathrm{C}$ above and below in situ temperature) usually experienced (Fig. 4A, B). The total variation of the experiments (i.e. manipulations $\times$ mesocosm variability or $2.3 \times 2.5=5.75$ ) is about the same as that of the diel data. However, we do not know exactly over what time scalcs these factors affect the Iell.TAR ratin: although the results showed that bacteria could respond to the changes of temperature and substrate supply at a time scale < hour and < day, receptively. The relative importance of these 2 factors in affecting the Leu:TdR ratio is still an open question. We speculate that during the low temperature period of the diel studies, temperature effects on the Leu:TdR ratio might be confounded by high rate of substrate supply which changed the Leu:TdR ratio from high to Iow (Fig. 3C).
Tibbles (1996) showed that Leu:TdR ratios showed a consistent positive correlation with temperature, in samples taken from several enviromments, and also with isolates. This pattern is just the opposite of the effects we have observed. We saw no consistent relationship between in situ temperature and the observed Leu:TdR ratio (Fig. 3), although ratios tended to be lower at higher temperatures. In the same kind of short-term manipulation experiments reported by Tibbles (1996), we observed that the Leu:TdR ratio declined with increasing temperature (Fig. 4). At present we cannot explain this enticing contrast in our results, except to point out that bacterioplankton communities from the coastal and open ocean sites studied by Tibbles (1996) have distinctly different responses and possibly different growth strategies than our brackish and estuarine samples.

\section{CONCLUSION}

In temperate estuarine ecosystems, limiting factors for bacterial growth such as temperature and substrate supply fluctuate over seasonal and diel cycles. To adapt to these changing environmental conditions, bacteria may reorganize their biochemical pathways by adjusting protein and DNA synthesis rates. Our laboratory results demonstrated that such biochemical adaptation could be determined by temperature and substrate supply. In the field, the Leu:TdR ratio seemed to be lower and more constant during high temperature and high chlorophyll periods. This indicates that bacteria may allocate more energy in reproduction than biomass accumulation under growth favorable conditions. Since the ratio of protein:DNA synthesis rates varied with temperature and substrate supply, we suggest that the compatibility of ${ }^{3} \mathrm{H}$-thymidine and ${ }^{3} \mathrm{H}$ leucine incorporation methods in determining bacterial production should be reevaluated. Simultaneous measurement of thymidine and leucine incorporation are not redundant, but provide independent information about bacterial growth status and adaptation strategies

Acknowledgements. This recparch was supported by grants from the NOAA-University of Maryland Sea Grant, and the NSF Land Margin Ecosystem Research Program. Support for F.K.S. was provided by the Department of Education (Taiwan, ROC), MD Sea Grant, Horn Point Environmental Laboratory and the EPA Multiscale Experimental Ecosystem Research Center (HPEL MEERC). We thank B. Tibbles (Dept. Zoology, Univ. Cape Town, South Africa) for sending us a preprint of his research and suggesting a relationship between Leu:TdR ratios and temperature. We thank Mrs W. Hsiao for assistance in the mesocosm experiments. Finally we acknowledge David Kirchman and Craig Carlson for comments on the manuscript and ongoing discussions 


\section{LITERATURE CITED}

Azam F (1986) Nutrient cycling and food web dynamics in the southern California Bight: the microbial food web. In: Eppley W (ed) Plankton dynamics of the southern California Bight. Springer-Verlag, New York, p 274-288

Berman T, Hoppe H, Gocke K (1994) Response of aquatic bacterial populations to substrate enrichment. Mar Ecol Prog Ser 104:173-184

Brunschede H, Dove TL, Bremer H (1977) Establishment of exponential growth after a nutritional shift-up in Escherichia coli $\mathrm{B} / \mathrm{r}$ : accumulation of deoxyribonucleic acid, ribonucleic acid, and protein. J Bacteriol 129(2):1020-1033

Chin-Leo G, Kirchman DL (1988) Estimating bacterial production in marine waters from the simultaneous incorporation of thymidine and leucine. Appl Environ Microbiol $54(8): 1934-1939$

Chin-Leo G, Kirchman DL (1990) Unbalanced growth in natural assemblages of marine bacterioplankton. Mar Ecol Prog Ser 63:1-8

Cole JJ, Findlay S, Pace ML (1988) Bacterial production in fresh and saltwater ecosystems: a cross-system overview. Mar Ecol Prog Ser 43:1-10

Ducklow HW, Carlson CA (1992) Oceanic bacterial production. In: Marshall KC (ed) Advances in microbial ecology. Vol 12. Plenum Press, New York, p 113-181

Fuhrman JA, Azam F (1980) Bacterioplankton secondary production estimates for coastal waters of British Columbia Antarctica, and California. Appl Environ Microbiol 39(6): 1085-1095

Fuhrman JA, Azam F (1982) Thymidine incorporation as a measurement of heterotrophic bacterioplankton production in marine surface waters: evaluation and field results Mar Biol 66:109-120

Harder W, Dijkhuizen L, Veldkamp H (1984) Environmental regulation of microbial metabolism. In: Kelly DP, Carr NG (eds) The microbe 1984, Vol 12. Cambridge University Press, Cambridge, p 51-95

Heinanen A, Kuparinen J (1992) Response of bacterial thymidine and leucine incorporation to nutrient $\left(\mathrm{NH}_{4}{ }^{+}, \mathrm{PO}_{4}{ }^{-3}\right)$ and carbon (sucrose) enrichment. Arch Hydrobiol Beih 37: $241-251$

Hobbie JE, Daley RJ, Jasper S (1.977) Use of nuclepore filters for counting bacteria by fluorescence microscopy. Appl Environ Microbiol 33(5):1225-1228

Kirchman D, K'nees E, Hodson R (1985) Leucine incorporation and its potential as a measure of protein synthesis by bacteria in natural systems. Appl Environ Microbiol 49(3): $599-607$

Kjeldegaard NO, Maaloe O, Schaechter M (1958) The transition between different physiological states during

Responsible Subject Editor: Farooq Azam, La Jolla, California, USA balanced growth of Salmonella typhimurium. J Gen Microbiol 19:607-616

Parsons TR, Maita Y, Lalli CM (1984) A manual of chemical and biological methods for seawater analysis. Pergamon Press, New York

Pomeroy LR (1974) The ocean's foodweb, a changing paradigm. BioSci 24(7):499-504

Riemann B, Bell RT (1990) Advances in estimating bacterial biomass and growth in aquatic systems. Arch Hydrobiol 25:385-402

Roman MR, Ducklow HW, Fuhrman JA, Garside C, Glibert PM, Malone TC, McManus GB (1988) Production, consumption and nutrient cycling in a laboratory mesocosm. Mar Ecol Prog Ser 42:39-52

Servais P (1992) Bacterial production measured by ${ }^{3} \mathrm{H}$-thymidine and ${ }^{3} \mathrm{H}$-leucine incorporation in various aquatic ecosystems. Arch Hydrobiol Beih 37:73-81

Shiah FK, Ducklow HW (1994a) Temperature and substrate regulation of bacterial abundance, production and specific growth rate in Chesapeake Bay, USA. Mar Ecol Prog Ser 103:297-308

Shiah FK, Ducklow HW (1994b) Temperature regulation of heterotrophic bacterioplankton abundance, production, and specific growth rate in Chesapeake Bay. Limnol Oceanogr 39(6): 1243-1258

Shiah FK, Ducklow HW (1995a) Multi-scale variability in bacterioplankton abundance, production and specific growth rate in a temperate salt marsh tidal creek. Limnol Oceanogr $40(1): 55-66$

Shiah FK, Ducklow HW (1995b) Regulation of bacterial abundance and production by substrate supply and bacterivory: a mesocosm study. Microb Ecol 30:239-255

Simon M, Azam F (1989) Protein content and protein synthesis rates of planktonic marine bacteria. Mar Ecol Prog Ser 51:201-213

Stevenson JC, Heinle DR, Flemer DA, Small RJ, Rowland RA, Ustach JF (1977) Nutrient exchanges between brackish water marshes and the estuary. In: Wiley $M$ (ed) Estuarine processes, Vol II. Circulation, sedimentation and transfer of material in the estuary. Academic Press, New York, p $219-240$

Tibbles BJ (1996) Effects of temperature on the incorporation of leucine and thymidine by bacterioplankton and bacterial isolates. Aquat Microb Ecol 11:239-250

Wicks RJ, Robarts RD (1987) The extraction and purification of DNA labeled with [methyl-3H]thymidine in aquatic bacterial production studies. J Plankton Res 9(6): $1159-1166$

Wilkinson L, Hill M, Miceli S, Howe P, Vang E (1992) SYSTAT for the Macintosh, version 5.2. SYSTAT Inc, Evanston, IL

Manuscript received: May 17, 1996

Revised version accepted: April 17, 1997 